\title{
PROMOTING LEARNING IN LAW
}

\author{
CAROL BOND AND MARLENE LE BRUN*
}

\section{INTRODUCTION}

Today there is considerable interest in the enhancement of the quality of university teaching. In part this could be attributed to a change of focus in educational research during the last twenty years. The mid seventies and early eighties saw the development of a particular approach to the study of student learning that has significantly influenced teaching in higher education. ${ }^{1}$ The critical incident in this development was the work of Marton and his colleagues at the University of Gothenburg, Sweden, who argued for studies which focused on the students' perspective and the ways in which they interpret their reality. ${ }^{2}$ Marton called the approach "phenomenonography". ${ }^{3}$ Phenomenonography assumes that an understanding or conception of a phenomenon can be described in terms of a relation between an individual and that phenomenon. This method adopts a relatively open interview approach which generates qualitative descriptions of our understanding or conception of the phenomenon under study. The Swedish research indicates that our conceptions govern the way in which we think and act in a particular context. For example, how university students think about or conceptualise learning influences the ways in which they approach their study. ${ }^{4}$ The research distinguished between surface and deep approaches that students adopted to a learning task. ${ }^{5}$ Thus the relatively recent change in focus in educational research is reflected in a growing emphasis on student learning outcomes rather than classroom teaching — what students learn rather than how we teach.

In parallel with others in higher education, University law teachers in Australia are now beginning to take seriously learning about educational theory. Moreover, they are beginning to apply this knowledge in a thoughtful and systematic fashion in their teaching. Seven or so years ago few law teachers in Australia would have discussed their work as legal academics in terms of promoting student learning. If they talked about education in law at all, it would, more likely than not, have been in terms of the need to improve teaching performance. Few law teachers at that time would have understood the significance of encouraging students to adopt deep approaches to learning. ${ }^{6}$ Fewer still would have appreciated the ramifications of adopting a student-centred approach to the teaching of law. Nevertheless, the climate in education in Australia has shifted noticeably particularly in the past two or three years as universities seek to promote excellence in all areas of academic work in their competition for student places and government funding.

Despite the rather marked changes in the university context of teaching and learning, and the shift in focus of educational research to an interest in student learning outcomes, little research has been conducted to date which provides us with insight into how students' ideas about law actually affect how they study law. In addition little information is available which focuses on how learning can be promoted by teachers who actively seek to identify students' conceptions and, more importantly, misconceptions of law and its study. Instead, much of the conversation about enhancing learning in law in Australian universities' law schools appears to proceed on the continuing (unchallenged) assumption that students enter and proceed through law school with minds which can be filled (moreover, which we as legal academics can fill) with "legal knowledge" by way of lecture and tutorial.

As part of our increasing understanding of research on student learning and teaching we are now realising that the teacher and learner form a dynamic relation. ${ }^{7}$ This research suggests that law students do not enter the legal classroom as empty slates upon which we write the language and processes of the law. Rather, both teachers and learners perceive the teaching/learning context according to their own conceptions of legal epistemology, and the teaching and learning of law. Bain's ${ }^{8}$ simplified conceptual 
model summarises this relation between teaching and learning in law. (See Figure 1 below.)

In this article we focus on research which has emerged from the early Swedish work, and we examine its implications for teaching and learning in law. We use the concepts of approach and conception that have been developed in the educational literature. We illustrate their relevance to law teachers by using two case studies that have been generated from the interview data of two law students who participated in a preliminary study of students' conceptions of law in a law school in Australia. ${ }^{9}$ Using these cases, we show how a surface or deep approach to the learning of law is influenced by a particular conception of law and of the learning of law. We relate the two students' conceptions of and approaches to learning law to research on university teachers' conceptions of teaching, and we consider the implications of these relations for teaching and learning law. We do not, however, explore in depth the relationship between legal epistemology and learning outcomes, despite the apparent link between the two that is evidenced in our research.

Figure 1: Conceptions of Learning and Teaching: A Simplified Model ${ }^{10}$

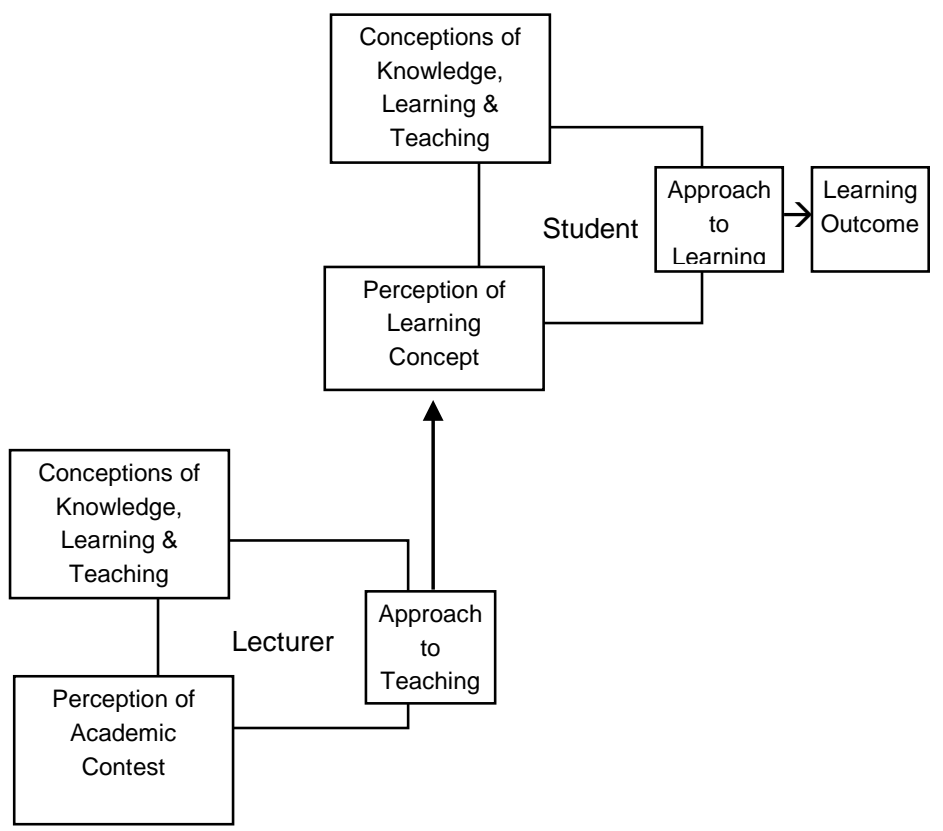

\section{APPROACHES TO LEARNING}

Marton and Säljö identified two distinctly different approaches to learning tasks — surface and deep. ${ }^{11}$ Ramsden ${ }^{12}$ suggests that the concept of approach to learning is one of the most influential to have emerged from the research into teaching and learning in the last fifteen years. Inherent in the concept is the idea of a relation between the person and what is learned. When we talk about learning we always talk about it in relation to learning something. The approach that a student takes to a particular learning task governs the outcome of learning - what it is that is learned. The two can be distinguished by the difference which is evident in the intention of the learner. When students take a surface approach, their intention lies solely in the completion of the task requirements. They tend to be externally motivated and driven by assessment requirements. They distort the meaning of the learning task, that is the teacher's pedagogic intention. For example, they unthinkingly rote learn curriculum material rather than trying to understand what the material represents. They may form unrelated parts of the task, memorise information for assessment, and fail to associate facts and concepts or to distinguish principles from examples. ${ }^{13}$ When students take a deep approach to a learning task, their intention is to understand, and they tend to be internally motivated to learn. They focus on the meaning of the task and relate both previous knowledge to new knowledge, and knowledge from different subjects. They associate theory with everyday experience, distinguish evidence and argument, and organise and structure knowledge into a coherent whole. ${ }^{14}$ Thus there is a major distinction between whether students accept and reproduce information that is presented to them or 
transform knowledge and make it their own as part of a process of coming to understand it for themselves. ${ }^{15}$

\section{CONCEPTIONS OF LEARNING}

Conception as it is used here, and more generally in phenomenography refers to the meaning that we place on the relation between a person and a phenomenon in the world - that person's experience of a particular phenomenon. If the phenomenon is law, then one's conception of law is the meaning that one gives or understanding that one has of that experience. ${ }^{16}$ Marton argues that there are a limited number of qualitatively different ways in which any phenomenon may be understood or experienced. ${ }^{17}$ The research on conceptions of learning shows this limited variation.

The term conception of learning was first adopted by Säljö over twenty years ago. Using individual interviews he asked a group of adults how they understood learning. ${ }^{18}$ The study revealed five qualitatively different conceptions of learning: learning as an increase in knowledge; learning as memorising; learning as an acquisition of facts, procedures etc. which can be retained and/or utilised in practice; learning as the abstraction of meaning; and, learning as an interpretative process aimed at the understanding of reality. Säljö's study has since been replicated several times. ${ }^{19}$ In a later study of students at the Open University in the UK, Marton, Beaty and Dall'Alba ${ }^{20}$ six conceptions of learning, the first five of which were similar to those of Säljö: increasing one's knowledge; memorising and reproducing; applying; understanding; seeing something in a different way; and changing as a person.

The first three conceptions of learning see knowledge as the acquisition of atomistic or discrete pieces of information which are to be learned as they are presented or given. The emphasis is on the amount of knowledge that is learned, and learning is thus described in quantitative terms. For instance, students might say that they are learning a lot of things. Knowledge is characterised as information or facts and figures knowing a lot of facts. Other examples indicate that learning is understood in terms of the brain as a vessel to be filled - filling one's head with knowledge, storing information and being able to reproduce learned material exactly as it was given - learning by rote. The learned material remains unchanged, for example, when a student describes learning in terms of reproducing information for exams. Alternatively, learning is applied in a practical way, and the emphasis is on being able to retrieve the information and use it when the need arises. These three conceptions often characterise learning in terms of a consumption metaphor. ${ }^{21}$ Learning is something external to the knower: information is to be collected or consumed. These conceptions are associated with the adoption of a surface approach to learning.

In contrast, the last three conceptions of learning focus more on gaining meaning: seeking understanding of the material to be learned. Students talk of looking into things and having a view of things. Learning is a way of seeing or grasping something. In the last two conceptions it is evident that there are different ways in which something can be understood. The learner talks about learning as seeing something in a different way, understanding something differently, having different perspectives. The emphasis is placed on the way in which things are seen from different perspectives and how they are related to each other, parts to greater wholes. ${ }^{22}$ These last three conceptions indicate a change in skill, from the utilitarian view of learning as applying, to grasping something and changing the way in which one looks at something. The conceptions are characterised by a change in the way students perceive their role in learning - a change from a relatively passive acceptance of material that is provided to an active engagement in learning and a search for understanding. Indeed, the sixth conception, learning as changing as a person, involves the idea of learning as change. By developing insights into or a view of the learning material, one develops a new way of seeing the material, and, in so doing, one changes as a person. ${ }^{23}$ This conception has a very personal focus and emphasises personal growth. In contrast to the consumption metaphor of the first three conceptions, visual or physical metaphors predominate in the last three. Students conceptualise learning as a transformative process. Knowledge gained from external sources or previous experience is constituted or reconstituted into personal meaning and understanding. ${ }^{24}$ These last three conceptions are associated with the adoption of a deep approach to learning. Moreover, implicit in both research on conceptions and approaches is the notion that these conceptions are characterised by a search for understanding and meaning. It is this search and the adoption of a deep approach to learning that enables students to learn more effectively 


\section{Conceptions of Teaching}

Parallel to the research described above is a growing appreciation of the complex inter-relationships between university teachers' conceptions of knowledge, their conceptions of teaching, and student learning outcomes. Thus, for example, the way in which teachers conceptualise their teaching and approach their teaching tasks has direct implications for the way students learn. ${ }^{25}$

Ramsden ${ }^{26}$ summarises this work in his description of three generic conceptions of teaching: first, "Teaching as telling" in which a teacher sees teaching as the transmission of knowledge and learning as the process of knowledge acquisition; second, "Teaching as organising" in which teaching is conceptualised as a management activity in which learning problems are "fixed by recourse to the "right" strategy; and third, "Teaching as making learning possible" where teaching and learning are seen as parts of one complex, compound, indeterminate whole, the aim of which is to improve student learning. ${ }^{27}$ In the third conception, the role of the teacher is to attempt to understand and to rectify students' misconceptions by discovering, through constant vigilance and monitoring, the "critical barriers to student learning. ${ }^{28}$

These generic conceptions of teaching parallel the conceptions of learning described above in terms of their increasing complexity or hierarchical structure. The first possibly derives from a conception that knowledge is something external, given, and prescribed, while the last is distinctly relative and assumes that we each constitute our own world view.

\section{THE PRELIMINARY STUDY}

The idea for the research that is discussed in this article arose when we began to redesign the Australasian Law Teachers Association (ALTA) Law Teaching Workshop. ${ }^{29}$ One of our aims for the Workshop was to raise the Workshop participants' awareness of the relation between students' conceptions of learning and its context, and the approach to study that they adopted. ${ }^{30}$ To do so effectively we believed that we needed teaching aids that would vividly illustrate this relation and the way in which it influenced students' study of law; however, there was no previous research to draw upon for Workshop purposes. Since we did not have sufficient time to undertake a full empirical study before the Workshop, we decided to conduct a small, preliminary study of students' conceptions of and approaches to learning. It is this research which also provides the data for the case studies reported below. We refer to it as a preliminary study because of the need for a larger study of law students' learning that we hope to conduct in the future. Although the full outcomes of the preliminary study will be reported elsewhere, we provide a brief description of the method that we employed and discuss some of our findings below.

\section{RESEARCH METHOD}

We asked the first year class of approximately 160 students at Griffith University if they would volunteer to be interviewed about their conceptions of learning and of learning law and their conceptions of and approaches to a recent assignment. They were told about the Workshop and the use to which the interview material would be put. The sample of ten law students consisted of six females and four males who were enrolled in a range of integrated degrees.

Our interviews with the students were approximately one hour in length and were conducted in May 1994, ten weeks after the commencement of the academic year. The interviews were video-taped because videos provide an excellent visual illustration of important concepts and their interrelations. Extracts from three of the video tapes were used for the preparation of the teaching material for the ALTA Law Teaching Workshop, which was held in July 1994. The interviews were also audio-taped so that they could be fully transcribed; the transcriptions constitute the data for this study. Permission from the University was obtained. Students gave their informed consent to be interviewed using video and audio tapes, and for the interview material to be used for the ALTA Workshop.

The structure of the interview was based on the phenomenographic approach and consisted of ten main, open-ended questions. For example: "What is it you want to get out of studying law?" and "What would you say learning is in general?” For each of these questions a set of planned probes was prepared. The probes that we used in any one interview depended upon the student's response to the previous question. 
Probe questions ranged from: "Can you tell me more about that?”, "What does that mean?”, "How do you see that?”, “Could you clarify that?” Students’ approaches to learning were explored using a recently submitted assignment (a Client Advice Letter) in which students were asked to write a summary of a point of law on a hypothetical contract law fact situation. The summary was to be included in a letter to a senior partner in a law firm. Attached to the assignment were instructions which included its detailed pedagogic aims and objectives and guidelines for its completion. Students were asked to bring their client advice assignment with them to the interview.

\section{THE CASE STUDIES ${ }^{31}$}

The interview transcripts of two students who participated in the preliminary study were selected to provide case studies which illustrate both conceptions of and approaches to learning and their complex inter-relationship. For the purposes of this paper the students are called "Joe" and "Luke". Their transcripts were selected because these two students showed marked differences from each other in their rationale for studying law, their conceptions of legal knowledge, their conceptions of learning, and their approaches to the assignment. For each case study, interpretation of the data was made in the context of the whole interview transcript. Analysis involved reading and rereading the transcripts with a focus on the meaning that students attributed to law and learning, and the relations between these two: what constituted the study of law and how the students approached their studies. We selected text extracts from the transcripts to illustrate each case study. We use: an ellipsis (...) to indicate where irrelevant or repetitive material has been deleted; underlining to emphasise important concepts; and italics to indicate the questions that we asked in the interview. In each case study we discuss the student's conception of learning, his conception of law and legal knowledge, and his approach to the assignment.

\section{Joe}

\section{Conception of Learning}

Joe's conception of learning was similar to Marton, Beaty, and Dall'Alba J's third conception learning as applying. ${ }^{32}$ For Joe learning was

[p]ossession of knowledge of something you didn’t have before, ...I wouldn’t see learning as learning something I already know, it would have to be something new. So knowledge that I didn't have previously that I have now. ...ability to recall. ability to draw on. I'd have to include in that ability to repeat. to write down. or to speak about what I've learned and it's very redundant having learned something if you can't tell someone else about it.

So when you say the ability to recall and communicate it's actually explaining something or it's telling them?

It doesn't have to be explained but to be able to use that piece of knowledge that you've gained to do, if it is to teach somebody then to teach somebody, to apply that to a case, to apply that to giving an oral presentation...

\section{So application means?}

Application means using that knowledge for whatever purpose you see as being relevant.

Joe's focus on the application of what is learned is emphasized in the excerpt above. It is explicit in the latter part of the passage but it is also present in the first part in which he spoke of the use of knowledge for assessment purposes - writing it down, applying it to an oral presentation or to a case. For Joe, learning had a utilitarian value and purpose. He emphasized how the knowledge was to be used rather than the meaning or understanding of what he had learned. The consumption metaphor was evident in Joe's use of the word possession. Later in the interview when Joe talked of understanding there was no sense of anything more than a reproductive understanding of learned material. He tended to focus on accuracy rather than meaning. For example:

(Understanding is) ...(feeling comfortable within yourself that your conception, knowledge of something, is accurate.

The passages above show how the first two conceptions of learning, learning as increasing one's 
knowledge and learning as memorising and reproducing are subsumed in the third conception, learning as applying. Indeed, Joe's use of "recall” and "repeat" indicated the use of memorization.

\section{Joe's Conception of Law and Legal Knowledge}

“Application” also governed Joe’s rationale for studying law and his conception of legal knowledge:

... what is it that you want to get out of studying law?

... I would say it's going to be something in the public sector because of the specialized nature of the studies I have done in my other degree.. . because I have studied a lot of cultural, a lot of history, a lot of politics. a lot of contemporary issues, and a lot of international relations theory... I would be looking at putting that into practice using... the skills I see as ... being pertinent to law being those of being able to take information and use it the way society uses it to control a situation, to make decisions about various aspects of business, public policy.... Because I see our whole society being governed by law then I feel it touches on everything so if I can take that knowledge, no - not necessarily the knowledge - if I can take the ability to locate that knowledge, pick up the skill of being able to find the piece of knowledge that I need relating to the law which governs everything.. .

You mentioned earlier legal knowledge, what would you say is the nature of legal knowledge?

A better understanding of the rules by which we're governed by the way people interact, by the way business interacts, governments interact.... So I guess I see the rules as being a set of outlines or criteria that can or cannot be obeyed or can be used as a guideline.

In these passages Joe revealed his conception of knowledge and his conception of law. Knowledge was perceived quantitatively as discrete parcels, "pieces" or lots. The law is rule-based. Legal practice was the application of rules. He saw application as skill, and his learning in law focused on the acquisition of the skills by which he could apply the rules of law. This notion of legal knowledge is further exemplified in the passage below:

I really think that before I came to law (school) I had this conception that lawyers just walked around with a lot of statutes, urn, cases in their head and they just plucked the appropriate one out and slapped it on the table when it was needed, when the truth of the matter is they just need to know how to use the library I mean OK I need to gain a basis of skills in order to be able to know what to go and look for, but I really thought it was merely going to be an inputting of information and that I would just trot that information, ...I thought it was just going to ...(be) here's a case, here's a statute you know, here's a by-law, this is the rules and then I trot them out as needed. Now I really feel that it's more a matter of - OK, they're all available for any person who can read and write to go and look at. It's being able to do something with that information. knowing what to do with the information once you have it. So I see that skill now as anybody can get the information but I'm learning what to do with it.

Joe's conception of skill was the "doing something with the information". The skills were directed at the acquisition (input) and application (trotting them out as needed) of knowledge, rather than the constitution of meaning. The focus on "doing something with it" was a focus on application. In these passages it was also evident that knowledge was external to the knower, an external entity which was acquired and applied. The rules of law were a "given".

\section{Approach to Learning}

The way in which Joe's conception of learning and legal knowledge influenced his approach to learning law is illustrated in the following passages. Joe was asked how he went about learning:

I guess I personally learn by rote. repetition, I just have to do things over and over and over again.... I'm not really sure I've got it until I can repeat it back to myself frontwards, backwards upside down, inside out so, yeah, I tend to learn by rote so if I repeat things, if I go over them frequently it doesn't have to be at set intervals, it can just be the week before exams then I guess that's the way I learn specifically. I just go over the same material over and over again until I am familiar with it. Joe's approach to learning also appeared to be governed by application. Not only did he focus on the use of knowledge in a broad sense, he also used written and verbal repetitive strategies in order acquire knowledge. He adopted a surface approach, and learned by applying the knowledge repetitively in order to learn. Students who conceptualise learning as applying commonly adopt this circular strategy. ${ }^{33}$

\section{Joe's Approach to the Assignment}

In the passages below Joe described his initial response to the client advice assignment.

When you first saw or read this assignment outline ... what was your response to it?

Um. A little confused (be)cause there was a couple of grammatical things in there that confused me a little ... Um ... 
there was a grammatical error in so far as it appears that you are applying for a job within your own law firm, so I just took it to mean that I wasn't applying for a job within my own law firm and went on from there. I mean it was a pretty basic thing to make a decision about, but ... after that initially I was very relaxed about it, I didn't feel that it was going to be that big a drama to handle but that's probably two years of social science, you know, huge, big essays so I just think I probably approached it as a social science essay with a letter attached to the front....that was the strategy ... (they) were the skills that I had so they were the skills that I approached it with. Ah, combined with the skills that I had been learning about implementing case law to make my point rather than using text books to support my argument or lecture notes to support my argument.

Joe appeared to be distracted by the detail of the assignment. Here he focused on the superficial aspects of the text rather than the meaning as whole. Note again the mention of application of skill in his approach. He was asked what he thought was the main intention of the assignment.

... could you describe .... what you saw when you did the assignment. ... why did we set this assignment? That sort of thing.

I guess I thought you set the assignment to, one, see if we could write a business letter. Two was to see if we were able to apply what we'd been learning in class to a hypothetical, outside of the classroom where presumably we got very little input from outside. ... I just saw it as an applying of skills.

What do you think the assignment was about fundamentally?

Fundamentally teaching people who've no business experience the sort of things that they would need to do to interact with a client, to interact with an employer ... um .... at a written level. And specifically as a lawyer, not as just a private citizen or a business person but, yeah, specifically as a lawyer.

So what things were they?

Standard business procedure for the letter I would have thought, which possibly a lot of people don't have that skill so, you know, that was something you would expect a lawyer, you know, if you were employing a lawyer you'd expect them to be able to write a business letter so that was just, you know, a basic skill — business-letter writing. Um, that was the first thing.

Students who adopt a surface approach often misinterpret or distort the intention of the learning task. This kind of distortion is evident here. Joe incorrectly identified the fundamental purpose of the assignment as the writing of the business letter, thereby denying the primacy of the hypothetical. To illustrate:

[H]ow did you go about the assignment? Could you say a bit more about when you went to do it, write it — how did you go about that?

Sat down with my text book and my case book and the instructions, um, had a lot of fun making up the letterhead on my computer! And then basically looked at what word limit I had left ${ }^{34}$ and went hmm this is going to be fun!

When you did the assignment, when you said "Well, it's seeing if we can write a standard business letter," did you look at it in terms of an understanding or a demonstration of legal knowledge?

\section{Demonstration.}

Again the passage above indicates that Joe adopted a surface approach. He is concerned with structure, format, and word limit rather than the underlying meaning of the task. Joe went on to describe his interpretation of the second part of the assignment:

The second thing was a little more complicated in that it was stating/outlining law, making an argument, $\underline{I}$ saw it as making an argument to support the position which I took. I immediately having read this took a position and said, "OK this is what I am going to argue," and went from there.... I looked at the facts and with a little bit of knowledge of case form that I have so far I decided that, "yes there was a contract”, "yes it was binding”, "yes it should have gone ahead. I didn't know what the outcome of that would (be) if it ever went to a court situation but that was just my feeling about how it should end up and so that was what I argued.

I think the instruction was to advise a client. Why did you interpret "advise" as an argument?

Because if I am going to advise someone I have to believe what I am advising them to do, I wouldn't advise them against what I thought was in their best interests. I mean I wouldn't say to them, "walk out in front of a fast moving car so that you can get a nice big insurance claim. I would say to them, "you know, that's a really stupid thing to do", so I felt there was a binding contract so I would have to advise them that way So OK I was going to make a 
proposition for advice but I felt that I would have to feel secure in arguing this position. If I am going to advise them to do that then the logical follow through of that is that at some point I am going to have to argue this, so if I have to argue this point then I have to be confident that that's it, that that is what I'm saying, you know, that the advice I am giving I can support that with evidence with an argument. So, yeah, I did the backwards procedure I guess. I came to the argument and then got to the advice later.

Here Joe equated giving advice with mounting an argument. When talking about how he answered the hypothetical, Joe discussed the four elements of contract formation that had been considered in class.

What other issues did you see coming through in this assignment? ...Things we have covered in the elements of the formation of a contract?

I immediately went to the four major elements of the contract - intent, acceptance, offer, and consideration, ah and if I recall correctly I basically said, "OK intent is minimal, offer is minimal, it's the acceptance that's important here and the consideration is irrelevant as far as I was concerned”. OK all the elements had to be there but I was just immediately focused on acceptance and I actually framed my response, ... (I) decided what point I want to make under intent, ...there was intent and this is why it was commercial situation so I have to negate any family linkage. ... I now have to find a case to support that and "splat" that in there so there is a sentence about why it's a commercial setting and how this states intent rather than the domestic situation and here's the case that supports that. And then I went to each point in that method. So as soon as I found a point I wanted to make - that was what I included and I just found a case to support that argument because basically I had it stored in memory anyway I just had to leaf through and find the appropriate case from my books. I mean.... it was easy enough for me to recall, ...offer, intention - invitation to treat rather than offer on to the next section.

Note in his response his concern with the structure of the assignment - the main headings, the introduction, the need to "splat" in cases to support the points that he makes. Although Joe adopted a linear process of analysis that many law students employ, he focused on the surface elements of the task. The "application" conception is evident again, as is demonstrated below.

What was it about this particular task, the underlying law you have just outlined, those four areas. What was it that made you say that the focus is there rather than?

... because of what we've studied and the facts that were given in the hypothetical my assessment as I went along was, the intent seemed very clear to me, I didn't see it as being in question. I could apply the case law that I'd learned to date and my concepts, my understanding of what construed intent, I looked at the intent in the hypothetical and said, “yes there is intent,” ... and I tried to argue against it and found that it was difficult. It wasn't impossible.

So you were taking both sides?

Yeah, I looked at both aspects and found that the for case was far greater in my conception, so I went, "OK that's that issue dealt with" and then I went to the offer and again I looked at it and applied the case law that we'd done to date and went, "OK it seems to me that this fits in these pigeon holes therefore, yes we have an offer". Tried to argue the other side and said, "well maybe you could but it's pretty iffy", um, so OK we threw that one over and then we got to acceptance and that was the first time I felt like maybe, maybe there was some grey areas, there was some doubt in my mind as to whether it was as clear as it could possibly be. While I was certain in my own mind, at the end of the day that, "yes" there was an acceptance and this was the original one that was posted - there was a lot of other stuff put in there to add to the confusion to make life difficult for us basically (laugh) and to make us look at fifty more cases than we really wanted to look at!

The use of the pigeon hole metaphor reveals how Joe's atomistic conception of knowledge affected his approach. In the extract below he used the metaphor to describe this approach in more detail and then described his difficulties in synthesising knowledge and seeing the "something" as a whole.

You talked about putting information into pigeon holes, like you put this in that pigeonhole and you deal with if. Could you explain that and describe what you mean there? ...in my own mind I tend to break law into pieces like those pigeon holes. ... I ...break my cases up into the ones that relate to intent, the ones that relate to offer, and the ones that relate to acceptance. I can see now that when we go back to them, some of them do have other points, and yeah, you can put them in several pigeon holes but I still pigeon hole them. I would still say that I file them away in my mind as, OK, this is the one about intent, this is the one about offer, this is the one about acceptance, this is one where performance is the same as acceptance, and I actually pigeon hole them into that.

How big are your pigeon holes? In your mind do you have a mental picture?

Yeah, ...I actually have a picture, yeah, ....actually using visualisation to do that, what ...I actually feel like I have a box down here on the floor and above it I have a whole wall of pigeon holes with things like offer, intent, social, domestic, and I would stand, visualise myself sort of standing in front of that and going, OK, here's the case, the problem I have in front of me. Which of these pigeon holes am I going to need and which ones of these cases out of 
here should I put into these pigeon holes today to address this problem? I would actually pull them, yes, so they're probably all mixed up at the minute, but when I go to approach a problem I actually pull them out and put them into the boxes and then deal with them from there. Which is probably a convoluted process but it's the one I use.... OK, I can see that now thinking about it, it (the knowledge) is inter-related ... Well there is some overlap. I really see it as being quite ...each piece that we're learning as being distinct, and I'm actually having a bit of a problem now, ...(be)cause it was very obvious to me last week that we wound up a group of thoughts, and I've actually sort of been saying to my fellow students the last forty-eight hours, I really think we should sit down and try and put this into something, because I've got all these pieces, and I don't really feel like I've cot a composite. I feel like I've got pieces. Now, whether that's me, or whether it's other people, but you know, it was obvious to me that ... OK, I thought we had all these pieces but that we don't. We actually have a thing. I didn't realise I had a whole thing. I thought I had lots of pieces ... I can see that it's there but I don't think I have a very good grasp of it... I think I concentrated too much on the individual pieces to be able to see it as a composite.

Overall, it is clear from Joe's description that he adopted a surface approach to the assignment. He accessed cases from "pigeon holes" that he had created and "splat(ted)" them into a place in the assignment with points of law that he thought were relevant. He also described "holes" in his "theory" which he needed to "plug". In the last part of this excerpt he provided ample evidence of the impoverishment of this conception of, and approach to, learning.

\section{Luke}

\section{Luke's Conception of Learning}

Luke's conception of learning was more like Marton, Beaty, and Dall'Alba's fifth conception, seeing something in a different way. ${ }^{35}$ For Luke learning was

... the taking in of knowledge and being able to apply it, the acquiring of skills. ... Being able to listen effectively, being able to absorb that, being able to assimilate that with my own beliefs that I have come into the class perhaps with or reading approached an article with. I think that is very important.

...you mentioned the word assimilate. How do you see that?

Well some things you really — how could I say you are taken aback by something you perhaps haven't seen from that view point before and you really have to weight it up with a very open mind, it's no good being narrow minded, and I think that's what learning is for me, being able to broaden my perspective, open my mind to other view points and ....assimilate that with my beliefs. ... fitting them ....into my belief system.

What happens if that knowledge is not compatible with your belief system?

Well ...really I would have to weigh it up as to its merits, obviously my belief system is very important, my moral views, etc. I'd definitely weigh it up, I don't discard it immediately. I'll probably think about it - from experience I know I'll dwell on it for a week or two, talk about it with, urn, people who are important to me, my parents, my peers, my friends and then, if I find it irrelevant or 35 Supra, note 19. really not to my liking or really there's no evidence to back it up, then I'll discard it, but I suppose it's always there in the back of my mind.

So you see learning as something that you can discard? No really, these are things that are always in my subconscious that I have built up arguments for and against and that I can always bring out and say, "Well this is why I believe why I believe”. Make a defence for what I believe ... rather than just doing it on blind faith, but having evidence...

Could you tell me more about how you see learning and skills?

I hope to come out of my learning process with at least the skills to study to learn again. Not, just perhaps a body of knowledge but also skills to acquire more knowledge and that's what I see learning. As equipping me to be able to do - to get the skills to learn more.

...what is the learning process?

Well, I don't actually, I don't think it ever ends, I think I'm in a continual learning stage, but really this is a very intensive learning process at the moment and that's at university.

When you talked about "acquiring skills” you said "faking in knowledge". What do you mean by taking in? You talked about open mind - could you describe that a bit more?

Yes, for me very much it’s a visual and oral taking in.... perhaps visual plays an important role but I tend to think 
mainly by listening. That is in classes, to people, to experiences things like that and then I do a lot of — how could you say - thinking about it afterwards - I dwell on what people say very much and analyse that afterwards - not so much at the time.... a reflection process.

The emphasis on skill in learning that Luke showed here is characteristic of the fifth conception. Skill is required to be able to transform knowledge and make it one's own. Luke reinforced this notion with his description of lifelong learning.

\section{Luke's Conception of Law and Legal Knowledge}

As with Joe, Luke's conception of knowledge and law appears to be governed by his conception of learning. For Luke legal knowledge is "very subjective”.

...( T)hat is coming from, perhaps, the experiences of academics themselves and judges themselves. The bias you can see that coming through, um, the policy consideration perhaps in the decisions that they've given, that their moral judgments, being from a Christian view point things like that. There is a lot of subjectivity involved in the decisions so far as I can see and discussing cases, that urn, the judges really - although it's not so clear, it's really quite subtle but their beliefs do have such incredible impact.

...you're focusing on cases and decisions — is that your view of law?

...previously before I would have started my law degree I would have said it was a system of rules. (But law is) so much of a broader thing that it involves society as a whole, judges as a whole and the legislature, the executive etc and encompasses all of that and really I couldn't pin it down actually

Luke's conception of law appears to parallel his conception of learning, seeing something in a different way. This is demonstrated in the way he understood the law and also in his acknowledgement that others may see the law differently. He had a holistic and dynamic view of law and society, and its interaction. His rationale for studying law also reflected this view.

What is it that you want to get out of studying law?

Mainly ... my aim for studying law is to help people. I really want to help society — it's very idealistic I'm aware of that.... I am interested in civil rights, things like that, and I'd like to be a barrister and I want to study law to learn how to practise law. ... really the freedom of choice, the constitutional freedom that we are granted in Australia, I'm very interested in that, freedom of religion, freedom of speech things like that and being able to uphold those and the people who are - perhaps oppressed, minority groups, that's really were my interests lie.

And how do you consider the law might do that? How might you do that?

Really by being familiar with how law interacts with society, being about to be proficient at practising law and being able to argue a case where the Constitution is upheld, where we don't have tyrants being able to overtake our constitutional freedoms that we have.

...you see the cutting edge of law being in the court room as opposed to being a legislator or something of that nature?

Yes, ... I think judge made law is very important and because it’s really the interpretation of the legislation ...the legislature makes law but it's the way it's interpreted I think is what you really would call the cutting edge ...

Luke's rationale for studying law is grounded in his ethical and moral position. In the passage above, Luke demonstrated how he saw learning law as the practice of the skills of law, rather than the skills required to acquire and apply prescribed knowledge. Luke's learning was embedded in the knowledge of the discipline of law. He approached his assignment in the same way. Luke's disciplinary skill-based approach is typical of this conception of learning. ${ }^{36}$ The three more sophisticated conceptions of learning are characterised by an increasing focus on the acquisition of a skill base, strategies, and competence in learning, which are immersed in the relevant discipline. Embedded in this fifth conception of learning is the notion of the competent and knowledgeable adult. Here we see the relation between conception of learning and conception of legal knowledge. In seeing something in a different way Luke took a relative position regarding the nature and function of law. He shows an understanding of law that is dynamic and interactive. This too is a characteristic of the more complex conceptions of learning. 


\section{Luke's Approach to the Assignment}

Luke differed from Joe in his approach to the assignment. For example, he recognised the pedagogic intention behind the learning task. Moreover, although both students' responses to the initial question were skill based, Luke’s response showed a conception of skill that mirrored his conception of law. Overall he appeared to abstract meaning rather simply apply his knowledge.

[W]hen you first read the outline of the assignment what did you think about it, what were you first reactions? I thought it was very practical, we're really getting into what perhaps you may do later on quite quickly 1 was very impressed with that, that it was a client advice letter.

What do you think was being got at by that assignment? What was the aim?

Um, really I think the aim was to throw us students in at the deep end in a sense and see where the problems are, get some feedback on how we were taking in or trying to take in the information.

What sorts of problems?

... simple things, did we know how to cite a case, did we know how to get issues out of a hypothetical fact situation. which is quite important...we've had report backs to lectures on hypothetical fact situations but not really one has been affected so I think, perhaps, the need was seen to really focus on — is every one getting this right.

Would there be any other way, reasons that you think we might have set that assignment? Any other things that you could think of?

...what level of understanding we are at ... Really to gauge the effectiveness thus far, of the lecturing perhaps, the small groups, the large groups, and to see whether they were effective in being able to convey knowledge, to convey information about contract and see how are the students are failing so far.

In the next passage he elaborated his understanding of the task. Note how Luke's response differed from that of Joe. While Joe focused on arguing the case, Luke recognised the difference between providing advice and marshalling an argument.

When you read the assignment what did you think was wanted from you as a student?

Really what were the issues, how could you apply them to the facts and come up with an answer. I really didn't feel that my answer was wrong in any way but I could be right as long as I argued it well and I think that was stressed as well in the lectures.

So you saw it as a process of arguing for the client or?

No not really Hm arguing I think you have to put forward a very persuasive position. Whereas with advising I think you have to give the pros and cons in a very — how could you say — a very aloof or arms length manner, so I didn't see it as an argument.

So you see it as advising?

Yes, not arguing, I see a difference there. ... arguing I see as being very persuasive, bringing up the others' view points and really saying, "well these aren't relevant or irrational”. Whereas advising ... you would bring up both sides and really one, you could say one, side has more evidence than the other, therefore I would advise such and such. Taking legal action or not.

Here Luke focused on the main task. He identified the practical nature of the assignment and its direct relevance to the practice of law, and rather than devote excessive time to composing a cover letter, he gave primacy to the main task: the completion of the letter of advice to the client.

What did you think it was about, what was the substance of it?

Well, I thought it was about contract and that I didn't think about anything else really. I went through the three important steps - well two really going through what were the issues and then what were the general principles and then I applied them and came to a conclusion.

What made you do it that way?

From my previous studies in commercial law this was really, I could say, reiterated on a number of occasions and in 
our law lectures themselves it seemed to be, what is your conclusion initially, state the issues, the general principles, apply these to the facts then come to a conclusion.

It is evident that Luke took a deep approach to the assignment. He also illustrates how he saw learning as a process.

Two weeks before the assignment was due I read it over, I thought about it ...I was pleased that it was very applicable to what we'd been learning ...generally I like to read things early, leave them, if I think about them it's really subconsciously, then one week before, that was when the process really started... actually when I read it two weeks ago, the fortnight before rather, I thought about it and thought, "Hm, what's the issue?" "Acceptance - "Oh think about that, if I hear anything about acceptance in the next week grab it.. .” Then a week before I really thought "now my eyes have to open, I have to do some research myself, look up my text book as a main guide, my case book and then I thought ah ah!” Then that led me on further, then I had some ideas what was involved..

When you came to actually do the assignment, what did you do?

I read through the fact situation, I really did a flow-chart ... What was happening between the two parties, ...what was happening here. what was the issue, ... What was happening there, letter - was it a fax was it a telegram, what was the issue involved there $\mathrm{M}$ to $\mathrm{A}$ - things like that yes, I went through and really deciphered the facts situation first, highlighting issues next to it with a big coloured pencil.... I didn’t refer to my text book or anything at that stage, I went on my own knowledge_and then later I referred and saw what my problems were, or if there were are problems..

...you said you drew on your own knowledge then you went elsewhere, where was elsewhere?

To my text book, to my case briefs to see, ... we could only look at the cases we'd done so I knew some had to be relevant so I looked at the ones which could be relevant and picked them out....

In the passage above Luke demonstrated his search for understanding and his constitution of the meaning of the situation. The difference between Joe's approach and Luke's is illustrated in the following comment.

...[W]hy these cases were important, sorting them out in a pile, this was an offer, this case related to offer, this case related to acceptance. Very simple, this case was an intention case - I didn't know I would require them as yet then went to my text book and saw "Intention" - what were the presumptions for instance, what's relevant in this situation. Ah! therefore this is the case I will require. Went to the case brief, "how could I put that in?", "what was the issue here?", "was it the same?” yes.

...Are there any other things going on there?

...I thought about the issue... the fact situation. Sure, yes, whether the facts were similar...

Did this assignment contribute to learning for you?

Yes...In the sense of...not learning more about contract, I felt quite comfortable with what I'd learnt so far about that. Really, I didn't expand my knowledge to any great degree about contract, but learning in the fact that acquiring skills to do assignments, yes, in law, yes. It really reiterated that, as I mentioned before, you have your issues, your general principles, the application and conclusion. That really...umm....that's what I learnt ... And perhaps the application of using cases, yes.

So it sort of reinforces...?

Yes, yes, I think so .... Oh I'm sure there were some new things, but really that was more skill based. Yes, not knowledge based. I would contrast the two, yes.

In summary, Luke had begun to internalise the process of legal reasoning. He was able to construct a cogent argument in which he showed his perception of the relevance of context. Moreover, he adopted a deep and holistic approach to the assignment which enabled him to demonstrate an understanding of the role of principle and case, fad and issue, reason and conclusion.

\section{THE TWO CASE STUDIES: COMMENTS}

The two case studies demonstrate how the different approaches to the assignment adopted by Joe and Luke appeared to be intrinsically governed by their different conceptions of learning — and, moreover, by their understandings of the nature of law. For us as teachers, Luke's conception and approach is more 
desirable (and certainly more effective ${ }^{37}$ ) than that of Joe.

The presentation of these case studies has created an ethical dilemma for us. Our comparative analysis may lead a reader to conclude that we have labelled or stereotyped these two students. This is neither our intention nor our wish. We have used these case studies to demonstrate two qualitatively different ideas about learning law: they illustrate why teachers of law need to consider their teaching theories and practices. In short, our main purpose was to draw out from these examples some of the implications for legal education.

\section{Implications for Teaching Law}

Our preliminary research with first ear students in the Faculty of Law at Griffith University ${ }^{38}$ conforms with current understanding of how students learn. Students in law do demonstrate differing conceptions of law and approaches to the study of law. Our research suggests that, in order to be effective teachers, we first need to examine our own conceptions of teaching. Where is our focus? Is it on "Teaching as telling", "Teaching as organising", or is it, as the research suggests it should be, on "Teaching as making learning possible”? Research into student learning indicates that we need to shift our attention from teaching as presentation to focus more on student learning outcomes.

Second, we need to ask ourselves, How do our conceptions of teaching, learning, and legal knowledge and our approaches to teaching affect students with their own, and possibly different, conceptions of what constitutes learning, teaching, and legal knowledge? How do we address the needs of the Joes, Lukes, and others in our law classes? We reiterate. Research in education indicates that the focus of university teachers should be on the enhancement of the quality of student learning outcomes. In this paper we suggest that meaningful learning in a discipline such as law is only achieved if we become aware of the way in which our students understand teaching and learning law and legal epistemology. Thus learning in law is not simply the transmission of content or the facilitation of learning. It involves our active intervention to help students learn. If we wish to help students become skilled, lifelong learners who seek a transformative approach to their learning, then we must model a transformative approach in our teaching. We must set up a learning context in which students may challenge our conceptions and their own: one in which they construct their own knowledge frameworks.

But where do we begin? We could, for example, undertake a global, systemic review of our entire curriculum. This is ambitious and often impossible. We suggest that one key lies in an examination of our assessment schemas. To illustrate: consider what Joe and Luke say about their approach to the assignment. In designing the exercise, Le Brun's intention was to ask her students, first and foremost, to examine the substantive law, a goal which was stated in the instructions for the task and in the criteria for grading. Nevertheless, the design of the assignment was such that Joe was able to distort aspects of the task. From this preliminary research we see that we need to redesign the assignment so that more students are able to understand and respond to what is required. Such an intervention is a short-term (but often effective) strategy.

This research, however, indicates that we need to do a great deal more. We know that we need to understand how students learn. And we know that we also need to confront our own practices as teachers and understand the implications of what we do in relation to how students learn. Our research indicates that we also need to provide a safe context in which our students are encouraged to examine their own conceptions of teaching and learning law and legal knowledge. Moreover they need to be given opportunities to consider how these conceptions may ultimately affect their professional work.

* Associate Lecturer, Griffith Institute for Higher Education, Faculty of Education, Griffith University; Senior Lecturer in Law, Faculty of Law, Griffith University, respectively. A workshop on this research was presented by Le Brun and Bond at the 1994 ALTA Law Teaching Advanced Workshop. A version of the paper was presented by Bond and Le Brun at the 1994 ALTA Conference, and by Le Brun at the Lawasia Conference, Beijing, China, 1995 and at a seminar for the Faculty of Law, National Law School of India University, Bangalore, India, 1995. (C) 1996. (1996) 7 Legal Educ Rev 1.

1 J Bain, Understanding by Learning or Learning by Understanding: How Shall We Teach? An inaugural lecture by the Professor of Teaching and Learning, Faculty of Education, Griffith University, presented September 28,1994.

2 F Marton, On Non-Verbatim Learning 1: Level of Processing and Level of Outcome (1975) 16 Scandinavian J Psychol 273.

3 F Marton, Phenomenography — Describing Conceptions of the World Around Us (1981) 10 Instructional Sci 177.

4 F Marton \& R Säljö, On Qualitative Differences in Learning 11: Outcome as a Function of the Learner's Conception of the Task 
(1976a) 46 Brit J Educ Psychol 115.

5 F Marton \& Säljö, On Qualitative Differences in Learning 1: Outcome and Process (1976b) 46 Brit J Educ Psychol 4.

$6 \quad$ Id at 5 and F Marton \& R Säljö, Approaches to Learning, in F Marton, D Hounsell \& N Entwistle eds, The Experience of Learning (Edinburgh: Scottish Academic Press, 1984) 36.

7 See for an example of this perspective, P Ramsden, Learning to Teach in Higher Education (London: Routledge, 1992).

8 J Bain, Academics, Conceptions of Learning and Teaching: Implications for University Education, paper presented at Griffith University, 1994.

9 We are grateful to the students enrolled in Law and Legal Obligations for their participation in this research. We also wish to extend our thanks to Sue Collins and Chris Collins for their assistance with the student transcripts.

10 Bain, supra note 8.

11 Marton \& Säljö, supra note 6, at 36.

12 Ramsden, supra note 7, at 39. Chapter 3 (38-61) provides an excellent summary of the research in this area.

13 Ramsden, supra note 7, at 46.

14 Id.

15 NJ Entwistle \& A Entwistle, Contrasting Forms of Understanding for Degree Examinations: The Student Experience and its Implications (1991) 22 Higher Educ 205.

16 E Ekeblad \& C Bond, The Nature of a Conception: Questions of Context, in R Ballantyne \& C Bruce eds, Phenomenography: Philosophy and Practice (Brisbane: Queensland University of Technology, 1994).

17 F Marton, Revealing Educationally Critical Differences in Our Understanding of the World Around Us, invited address presented at the annual meeting of the American Educational Research Association, in New Orleans 5-9 April 1988, at 2.

18 R Säljö, Learning in the Learner's Perspective. 1: Some Common Sense Conceptions. (Reports From the Institute of Education: University of Gothenburg, 1979) 76. See also R Säljö, Learning and Understanding. A Study of Differences in Constructing Meaning From a Text, Göteborg, Acta Universitatis Gothoburgensis.

19 See, for example, EJ van Rossum \& SM Schenk, The Relationship Between Learning Conception, Study Strategy and Learning Outcome (1984) 54 Brit Educ Psychol 73; E Martin \& P Ramsden, Learning Skills or Skill in Learning? in JTE Richardson, MW Eysenck \& D Warren Piper eds, Student Learning Research in Education and Cognitive Psychology (Milton Keynes: Open University Press, 1987); and A Giorgi, A Phenomenological Analysis of Descriptions of Concepts of Learning Obtained from a Phenomenographic Perspective (Publikationer Fran Institutionen for Pedagogik: Goteborg Universitet, nr 18, 1986).

20 F Marton, E Beaty \& G Dall'Alba, Conceptions of Learning (1993) 19 Int'l Educ Res 277. The descriptions of conceptions of learning included here are summarised from this paper.

21 Id.

22 Id.

23 Id.

24 Entwistle \& Entwistle, supra note 14 at 15. See also J Bain, Understanding By Learning or Learning By Understanding: How Shall We Teach?, inaugural Lecture by Professor of Teaching and Learning, Griffith University, 1994.

25 See, for example, J Biggs, “Teaching: Design for Learning,” in B Ross ed, Teaching for Effective Learning (1990) 13 Res \& Dev Higher Educ 11; G Dall’Alba, Foreshadowing Conceptions of Teaching,” in B Ross ed, Teaching for Effective Learning (1990) 13 Res \& Dev Higher Educ 293; E Martin \& M Balla, Conceptions of Teaching and Implications for Learning, in B Ross ed, Teaching for Effective Learning (1990) 13 Res \& Dev Higher Educ 298; and K Samuelowicz \& J Bain, Conceptions of Teaching Held by Academic Teachers (1992) 24 Higher Educ 93.

26 Ramsden, supra note 7 , at 111.

27 Id.

28 Id at 114

29 The Australasian Law Teachers Association (ALTA) Law Teaching Workshop has been offered annually since 1987. The revised Workshop was presented for the first time in 1994. Our roles in the reconstruction of the Workshop were as an educational consultant and law teacher respectively. See M Le Brun \& C Bond, Law Teaching Reconceptualised (1995) 6 Legal Educ Rev 23. The review and redesign was part of a project funded by the Commonwealth Staff Development Fund under the auspices of DEET.

30 The design of the Workshop was based on Bain's conceptual model, supra note 8. Ramsden, supra note 7 provides an excellent overview of the perspective adopted in the Workshop.

31 We have protected the students' identity by disguising their names and circumstances. The case studies are not intended to stereotype the students and indeed we comment on this problem later in the paper. They are designed to illustrate the interrelationship of students' conceptions of learning law and legal knowledge and their approaches to learning.

32 Supra, note 19.

33 C Bond, work in progress (1996), Brisbane, Griffith University.

34 The word limit was 700 words.

35 Supra, note 19.

36 Id.

37 Joe was asked to rewrite his answer to the exercise. He received a credit for the subject. Luke did not have to rewrite his answer. He received a high distinction for the subject.

38 Nathan Campus. 